\title{
The Formulation of High-calorie and Rich-Fe Biscuits for Pregnant Women with Chronic Energy Malnutrition
}

\author{
Sunarti $^{1}$, Diffah Hanim ${ }^{2}$, Mustofa Ahda ${ }^{3}$, Ahid Mudayana ${ }^{4}$, Kusnandar ${ }^{5}$ \\ ${ }^{1,3,4}$ Universitas Ahmad Dahlan Yogyakarta, Indonesia \\ ${ }^{2,5}$ Universitas Sebelas Maret Surakarta, Indonesia
}

\begin{tabular}{l}
\hline \hline Article Info \\
\hline Article history: \\
Received Jun 20, 2016 \\
Revised Aug 23, 2016 \\
Accepted Aug 26, 2016
\end{tabular}

\section{Keyword:}

Anemia

Biscuits

Chronic energy malnutrition

Supplementary food

\begin{abstract}
Supplementary food distribution for pregnant women still depends on the local policy. This program is funded using Health Operational Funds and distributed in form of milk, eggs, raw materials such as green beans and others. The field constraints of this program were acceptability and willingness of pregnant women to process the raw materials. This study aims to address the problems of providing supplementary food for pregnant women who suffer from chronic energy malnutrition and anemia by making the formulation of high protein biscuits and $\mathrm{Fe}$ using soybean flour substitution catfish eggs and flour as a source of protein and Fe. Biscuits produced are expected to be one of the snacks and nutritions for women who suffer from chronic energy deficiency. The ingredients were flour, fish powder, soy flour, eggs, milk powder, sugar, and maize flour. The method used was pure experimental approach completely randomized design with three times repetition. The formulation of the biscuits proportion between fish and soy flour as much as $2: 1,1: 1$, and 1:2. Proximate test shows that the proportion of fish and soy flour 1:2 has the highest energy value (496.81 $\mathrm{kcal}$ ) with a value of $17.74 \%$ protein. Organoleptic test indicates that the most favourable taste and texture was the formulation with the proportion of fish flour and soy flour 1:2. The formulation of high protein and Fe biscuits for women with chronic energy malnutrition and anemia in Boyolali favoured by third trimester pregnant women is the one with the proportion of $1: 2$

Copyright $(0) 2016$ Institute of Advanced Engineering and Science. All rights reserved.
\end{abstract}

\section{Corresponding Author:}

Sunarti,

Faculty of Public Health,

Ahmad Dahlan University,

Jalan Prof. Dr. Soepomo, Janturan, Warungboto, Yogyakarta, Indonesia.

Email: inart2020@yahoo.com

\section{INTRODUCTION}

The problem of chronic energy malnutrition and anemia of pregnant women so far today, is still considered as public health problem in Indonesia. Based on data from basic health research 2013, prevalence of chronic energy malnutrition of pregnant women reaches $24.2 \%$ [1].

Low socioeconomic status causes pregnant women suffer from malnutrition and anemia [2]. Anemia prevalence of pregnant women as a risk factor of Low Birth Weight is still high, that is 64 percent [3]. The high prevalence of pregnant women with chronic energy malnutrition and anemia leads to the increasing prevalence of stunting children in Indonesia, that is from $35.6 \%$ to [4] $37.2 \%$ [1]. The average intake of protein for adult women in Central Java is $51.6 \mathrm{~g} / \mathrm{person} /$ day.

Providing supplementary food for pregnant women with Chronic Energy malnutrition is a kind of specific interventions included in the nutrition program of the first 1000 day of life [5]. The main purpose of feeding pregnant women with chronic energy malnutrition is to supply additional food intake to fulfill the 
nutritional needs during pregnancy [6]. Research by Prihananto, et al discover that supplementary feeding for pregnant women increases the consumption of energy and protein for pregnant mother [7]. The kind of supplying complementary food can be the food of manufactured products or traditional confectionary or local based food [6]. Since 2012, the department of health has issued recovery funds of Providing Supplementary Food for toddlers and pregnant mothers through the Operational Aids of Health in which the is Providing supplementary food prioritized on the implementation of local based food. The manufactured food can be used considering the packaging, labeling and expired date. The operational implementation is authorized on the creativity of each Primary Health Care [8].

In Boyolali there has been a program of Providing Supplementary Food for pregnant women funded by the Operational Aids of Health. The food provided is manufactured food and local based food such as formula milk, eggs, green beans, biscuits, and others. The constraint of this Providing Supplementary Food implementation is the compliance mothers to consume such food. Another obstacle is that pregnant women are reluctant to process the ingredients if they are given in the form of raw materials. The effective way to implement Providing Supplementary Food for short term is to provide ready-to-eat food such as providing additional food in the form of biscuits, milk or local based confectionary.

Biscuit is a kind of dry manufactured product made of basic ingredients such as flour, eggs, and margarine [9]. Biscuit is often used as a good alternative of Providing Supplementary Food for pregnant women or infants. Based on the result of basic health research 2013, there is $13.4 \%$ of the population above 10 years of age consuming biscuits more than once per day [1]. This shows that biscuit products have obtained the high power of acceptance in the community. Another advantage is that biscuit is light and has high value of calorie.

This research was intended to create a high-Calorie and rich-Fe biscuits formulation as an alternative confectionary to supply nutritional intake for pregnant women suffering from chronic energy deficiency and anemia so that they are expected to be healthy at the time of maternity. These high-calorie and rich-Fe biscuits are then fed as providing supplementary food for pregnant women suffering from chronic energy malnutrition and anemia.

\section{RESEARCH METHOD}

\subsection{Design of site location}

The method applied in this study consisted of two steps. The first step was making product formulation in pure experiment using Completely Randomized Design (CRD) approach [10] in three replications. Formulations of biscuits were made using mixture of ingredients consisting of wheat flour, cornstarch, milk powder, soybean flour, eggs, and fish flour. In this formulation the researchers used some high-protein flour such as soybean flour, egg, and fish flour, in this case was the catfish flour. It was expected to improve high values of protein quality by enriching the ingredient. Formulation between catfish flour and soybean egg flour implemented in this study had three kinds of proportion between catfish flour and soybean egg flour, they were 2:1, 1:1 and 1:2. Biscuit Formulation was served in 1000 gram of dough [4]. The substitution of catfish and soybean egg flour was $31.4 \%$ of the material. Biscuit-making was done by mixing dry and wet dough homogeneously, then it was placed into moulds and finally baked. The baking process was carried out at a temperature of $150 \circ \mathrm{C}$ for 15 minutes.

Proximate testing was done by analyzing the content of moisture, ash, protein, fat, carbohydrate, and Fe. After that, the organoleptic testing was conducted covering properties of color, texture, taste and scent and analysis of storing age by considering the number of mold colonies in biscuits stored in the 3 month period. Mold identification test was carried out in the Central Laboratory of the health in Yogyakarta.

The second step of this research was to test the acceptability of biscuits into the target subject. The design used in this acceptability testing was descriptive in which researchers only wanted to know the subject's acceptance towards the product. Sampling technique used in this research was accidental sampling [11]. The samples were 145 subjects consisting of productive aged woman, pregnant women and midwives as representatives of the healthcare provider.

The study was conducted in the laboratory of food technology and chemical analysis was done in BPPTK LIPI UPT Gunung Kidul in June - July 2014. The acceptability testing was carried out in Boyolali employing research subjects of periprenatal aged women, pregnant women, and midwives.

\subsection{Equipment and materials}

The tools used in this study included: digital scales for weighing foodstuffs, 60-mesh sieve, basin, mixer, pan, small plates, aluminum foil, and oven. Questionnaires for the acceptance test. Materials used are flour, milk, cornstarch, powdered sugar, soybean egg flour, catfish flour, margarine, and butter. 


\subsection{Research procedure}

The study began by making flour of catfish and soybeans-eggs with the help of a technician from UPT BPPTK LIPI Gunung Kidul. The process of making catfish flour and soybean-egg flour included the following steps:

1. Catfish flour was directly made by flouring process from catfish. The process of flouring catfish was done in several steps. The first step was weighing the catfish. In this experiment catfish used was as much as 20 $\mathrm{kg}$. After that catfish were cleaned and inside waste was taken. The second step was steaming catfish until half-cooked, and it could be separated between spines and skin. The third step was taking the flesh, removing the skin and bones then was steamed. The second steaming made the catfish flesh keep hot. The fourth step was pressing the flesh to separate the fat. The fifth step was baking process at a temperature of $55-60^{\circ} \mathrm{C}$ until the flesh became dry. The fifth step was flouring, and then it was sieved using a sieve of 80 mess. It was dried again. The sixth step was packaging [12].

2. Soybean flour-egg fortification. The purpose of using soybean flour fortified by eggs was to improve the quality of protein and to eliminate unpleasant odors in soybean. The process of flouring was as follows. The first step was weighing soybeans as much as $7 \mathrm{~kg}$, and eggs weighing $3.5 \mathrm{~kg}$. The second step was slicing tempeh thinly and then it was steamed for the inactivation of molds. Eggs were broken and blended. The third step was homogeneous mixing tempeh and eggs. The mixture was placed on a tray for baking at a temperature of $55-60{ }^{\circ} \mathrm{C}$. The fifth step was flouring process and it was sieved with 80 mess siever. It was dried at a temperature of $55-60^{\circ} \mathrm{C}$. Finally it was packaged [12].

3. The next procedure was conducting the experiment of the formulation of high-protein and rich-Fe biscuits, followed by testing of proximate and organoleptic as well as analysis of storing term considering the mold colonies found in biscuits. Boyolali.

The final step of this research was testing the acceptability towards the target subject conducted in

\section{RESULTS AND ANALYSIS}

\subsection{Optimization of biscuit formulation}

In this study the formulation of biscuits was categorized into three groups, they were biscuits A with the formulation of flour catfish flour: tempeh eggflour was 1:1, Biscuits B with the formulation of flour catfishflour: tempeh eggflour was 2:1, and biscuits $\mathrm{C}$ with the formulation of flour catfishflour: tempeh eggflour was 1:2. The result of the analysis of the biscuits can be seen in Table 1 .

Table 1. Nutritional Composition of Tekafe Biscuits per 100 gram

\begin{tabular}{cccc}
\hline \multirow{2}{*}{ Component of Nutritions } & \multicolumn{3}{c}{ Formulation of Biscuits } \\
\cline { 2 - 4 } & $\mathrm{A}$ & $\mathrm{B}$ & $\mathrm{C}$ \\
\hline Water (\%) & 10.20 & 9.19 & 5.82 \\
Ash (\%) & 1.36 & 1.32 & 1.39 \\
Protein (\%) & 17.87 & 19.53 & 17.74 \\
Fat (\%) & 25.69 & 26.58 & 25.13 \\
Carbohydrate (\%) & 44.88 & 43.38 & 49.92 \\
Fe (mg) & 5.88 & 6.33 & 8.57 \\
Energy (Kkal) & 482.21 & 490.86 & 496.81 \\
\hline
\end{tabular}

Source: Primary Data. 2014

\subsection{Results of organoleptic testing}

Organoleptic testing was carried out by 15 trained and untrained panelists. The elements tested were color, flavor, scent, and texture. The result of the testing scores was divided by the number of the subjects obtaining the following results.

Table 2. Results of Organoleptic Testing of Several Biscuits Formulas

\begin{tabular}{ccccc}
\hline Biscuit Code & Color & Flavor & Scent & Texture \\
\hline A $(1: 1)$ & 1.800 & 2.200 & 1.866 & 1.866 \\
B $(2: 1)$ & 1.600 & 1.733 & 1.866 & 1.733 \\
C $(1: 2)$ & 2.266 & 2.600 & 2.133 & 2.800 \\
P value & 0.05 & 0.004 & 0.5 & 0.00 \\
\hline
\end{tabular}

* Anova Testing (Source: Primary Data. 2014) 
Based on the results of ANOVA testing, it can be concluded that there was not any difference in preferences on the color element $(p=0.050)$, for flavor aspects $(p=0.004)$ and texture $(p=0.000)$, it means that there were significant differences in the three groups of biscuits. Based on these data the flavor and texture of the biscuits $\mathrm{C}$ were preferred compared to biscuits A and B. There was no significant difference $(\mathrm{p}>0.050)$ in scent elements. Viewed from the overall highest average of the elements of color, flavor, scent and texture, biscuit $\mathrm{C}$ (biscuits with flour composition catfish and tempeh $\mathrm{egg}=1: 2$ ) had the highest average value.

\subsection{Acceptability testing}

Acceptability testing was conducted in two groups, they were there groups of productive aged women, pregnant women, and midwives as representatives of the health personnel. The Results of Acceptability Testing can be seen in Table 3.

Table 3. Acceptability Testing of Biscuits of Perprenatal Aged Women Group

\begin{tabular}{ccc}
\hline Acceptance Testing of Biscuits & Quantity (n) & Percentage (\%) \\
\hline Like & 52 & 91.8 \\
Dislike & 5 & 8.8 \\
Total & 57 & 100.0 \\
\hline
\end{tabular}

Source: Primary Data. 2014

Based on Table 3, it can be seen that almost all productive-aged women as a panelist said that they liked biscuits (91.2\%). Therefore, the biscuits can directly be provided as supplementary food for pregnant women Trimester III.

Table 4. Acceptability Testing of Tekafe Biscuits on Pregnant Women

\begin{tabular}{ccc}
\hline Acceptance Testing of Biscuits & Quantity (n) & Percentage (\%) \\
\hline Like & 38 & 86.4 \\
Dislike & 6 & 13.6 \\
Total & 44 & 100.0 \\
\hline
\end{tabular}

Source: Primary Data. 2014

Based on Table 4, it can be seen that the test of acceptability shows $86.4 \%$ of pregnant women liked biscuits. This suggests that the high- calorie and Fe biscuits are worth-consuming as an alternative Providing supplementary food for pregnant women.

Table 5. Acceptability Testing of Tekafe Biscuitson Group of Midwives

\begin{tabular}{ccc}
\hline Acceptance Testing of Biscuits & Quantity $(\mathrm{n})$ & Percentage $(\%)$ \\
\hline Like & 25 & 83.3 \\
Dislike & 5 & 16.7 \\
Total & 44 & 100.0
\end{tabular}

Source: Primary Data. 2014

Based on Table 5, it can be seen that the test of acceptability shows $83.3 \%$ of midwives liked biscuits. This shows that the high-protein and rich-Fe biscuits are worthy-consuming for providing supplementary food for pregnant women in Boyolali.

\section{4. analysis of storing age}

The analysis of storing age was done by observing the mold colonies. After 3 months it was kept in sealed packaging and at room temperature, then analysis of the mold colony was conducted. The results are as shown in Table 6.

Table 6. The Results of Storing Age of High-Protein and Rich-Fe biscuits for 3 Months

\begin{tabular}{cccc}
\hline Parameter & Unit & Test Result & Standards \\
\hline Fungal Figures & Cfu/gr & 30 & Double Tube Cultures \\
\hline Primery Date. 2015 & & &
\end{tabular}




\section{DISCUSSION}

\subsection{Optimization of the formulation of high- calorie and Fe biscuits}

The protein content of the Indonesian National Standart for biscuit is (minimum 9\%) while in this study the protein content of the biscuit reached $17.74 \%$. This means that the levels of protein produced in this study has already met the quality of Indonesian National Standart biscuits.

The similar study used cork fish as a substitute material intended to increase the value of protein. The results showed that the protein content was $26.7 \%$, meaning that the protein level was higher than that of biscuits in this study [13]. This difference may be due to differences in protein levels in both types of fish. When compared with the minimum standard of protein content in the biscuit sandwich 15\%, [14] then the biscuits produced by this research has met the criteria of providing supplementary food for pregnant women.

The ash content has met the Indonesian National Standart (maximum 1.6\%) while the Tekafe biscuits contained $1.39 \%$. Minimum standards for fat content is $9.5 \%$ while the level of fat in Tekafe biscuits reached $25.13 \%$. It shows the biscuits produced in this study meet the ISO standard. Minimum Standart of fat for providing supplementary food according to the Health Department for pregnant women is $25 \%$ [14]. The fat content of biscuits produced in this study was $25.13 \%$. This means that nutrient fat standard also meets the criteria as providing supplementary food.

Micromineral measured in the high-protein and rich-Fe biscuits was Fe mineral. The content was $8.57 \mathrm{mg}$. Whereas the standard of Fe in biscuits suggested by the Ministry of Health related to the standard of providing supplementary food biscuits for pregnant women is $15 \mathrm{mg}$ [14]. The similar study was carried out by Ariani, et all by providing fortified FeSO4 biscuits, the obtained results are $9 \mathrm{mg}$ Fe/100 gram biscuit [15]. This result is slightly higher than that of this study. The similier study had result that intake biscuits with Fe fortification is important to improve daily intake of Fe but it is important to keep nutritional biscuits were not damaged when it comes to consumer [16].

The weakness of these high-protein and rich-Fe biscuits was that water level was still above the Indonesian national standard, so it affected the storing age. The high levels of water in Tekafe biscuits resulted from unoptimally-drying process equipment. However, the results of this study were in line with the research by Khasanah that is substitution of catfish flour for baby food biscuits showed water levels remain high at 6.56 but in general the biscuits have fulfilled Indonesian National standard [12].

Based on the results of storing age testing, it was shown that the age of fungi for 3 months still had a normal figure of mold from specified threshold that is $200 \mathrm{CFU} / \mathrm{gr}$ [17].

\subsection{Organoleptic testing and acceptability testing}

The results of organoleptic testing showed the biscuits which met the organoleptic testing were biscuits formula $\mathrm{C}$ with a ratio of catfish flour and eggs tempeh flour of 1:2. The biscuit with a composition of $1: 2$, the fishy taste of the catfish flour was less so the acceptability among productive aged women was better than those of formula biscuits A and B.

Acceptability testing was conducted on three groups of panelists, they were a group of productiveaged women, pregnant women, and midwives as a representative of health workers who frequently interact with pregnant women. Based on the results of acceptability testing, there were $91.8 \%$ of productive-aged women, $86.4 \%$ of pregnant women, and $83.3 \%$ of midwives as health workers, who could accept these biscuits well. This suggests that the biscuit formula was ready to serve as providing supplementary food for pregnant women Trimester III suffering from chronic energy malnutrition and anemia. Acceptability testing is said to be good if the number of the subjects refusing is less than $25 \%$ [18]. In this study, the subjects refusing was around $9-17 \%$, so it was less than $25 \%$. It means Tekafe biscuit products can be used as an alternative providing supplementary food for pregnant women at Trimester III suffering from chronic energy deficiency and anemia [4].

\subsection{Analysis of the portion determination of high-proteinand rich-Fe biscuits as PSF for Pregnant women with chronic energy malnutrition \\ Based on the standard of Department of Health related to the providing supplementary food for} pregnant women with chronic energy malnutrition is that the food must contain 300-400 kcal and 10-12 grams of protein. Based on the results of this research biscuits $\mathrm{C}$ were chosen by panellists, containing calories $496.81 \mathrm{Kcal}$ and 17.74 grams of protein per 100 grams of biscuits. So the dosage per serving for providing supplementary food is 60-80 grams of biscuits per day. 


\section{CONCLUSION AND SUGGESTION}

The most optimal formulation in this study is biscuit $\mathrm{C}$, with comparison between catfish flour and tempeh egg flour is 1:2, producing energy 496.81, 17.74 grams of protein and Fe of 8.57 per 100 grams of biscuits. The results of organoleptic testing shows that there is no difference in preferences on the color and scent of biscuits. While the taste and texture of biscuits $\mathrm{C}$ are more preferred than biscuits $\mathrm{A}$ and $\mathrm{B}$. The results of acceptability testing show that biscuits $\mathrm{C}$ have the value of acceptance covering more than $75 \%$ so that these biscuits can be served as an alternative program of providing supplementary food for pregnant women suffering from chronic energy malnutrition with a dosage of 60-80 grams per serving of biscuits.

It is strongly recommended to re-examine the formulation of high-protein and Fe biscuits to discover the potency of the antioxidants and other functional food as an alternative PSF for pregnant women Trimester III suffering from chronic energy malnutrition and anemia among poor families.

\section{ACKNOWLEDGMENT}

We would like to thank to the decentralization funding grantor of PEKERTI DIKTI (Higher Education), Research and Development Institute University of Ahmad Dahlan Yogyakarta, Graduate Program of Nutrition Science PPs UNS Surakarta, UPT BPPTK LIPI Gunung Kidul, and the whole range of the City Health Office in Boyolali so this study can be properly carried out and published.

\section{REFERENCES}

[1] National Institute of Health Research and Development Ministry of Health Indonesia, "Result of Basic Health Reseacrh 2013," 2013.

[2] Sitohang N. A., "Nursery Care for Baby with Low Birth Weight," Usu Digital Library, 2004.

[3] Muslimatun, "Experience of Maternal Suplementation in Indonesia," Presented in diatation Up Date, Malang, 2008.

[4] The Ministry of Health of Republic Indonesia, "Basic Health Reaseach, 2010,” 2010.

[5] Republic Indonesia, "Planning Guide Of National Program for Nutrition improvement acceleration at the first-1000 day of life," 2013.

[6] The Ministry of Health of Republic Indonesia, "Nutrition Guidelines for Pregnant Women and development of Local-based Supplementary Food," 2010.

[7] Prihananto V., Sulaiman A., Riyadi H., Palupi N., "The Effect of Supplementary food Giving toward Energy and Protein Consumtion," Jurnal of Nutrition and Food, vol/issue: 2(1), pp. 16-21, 2007.

[8] The Ministry of Health of Republic Indonesia, "Guidelines of Holding Supplementary feeding for recovery of baby and Malnutrition pregnant women," 2012.

[9] Ayustaningwarno F., "Food Technology of Practical and Aplicative Theories," Graha Ilmu, Yogyakarta, pp. 78, 2014.

[10] B. Murti, "Principles and Methods of Epidemiology Reseach," UGM Press, 2001.

[11] S. Notoatmojo, "Methodology of Health Reseach," Jakarta, Rineka Cipta, pp. 89, 2005.

[12] Khasanah Y., Anwar M., Ratnayani, Ditahardiyani P., Ariani D., "The Usage of cat fish (Clarias) in Toddler Biscuits Making," The Annual National Seminar of Fishery and Oceonagraphy Research, 2008.

[13] Afrianti, "Fish Cork Cookies as Supplementary Food for Pregnant Women in the Third Trimester," Seminar Proceeding of Fakulty of science Lampung University, 2013.

[14] The Ministry of Health of Repubic Indonesia, "Decision of Health Ministry No 899/Menkes/SK/X. about Technical Specification of Supplementary Food for Pregnant Women," 2009.

[15] Ariani D., Suharwadji, Angwar M., Kurniadi H. M., Khasanah Y., Ratnayani, et al., "The Functional Food Development with Iron Fortification to solve Iron Deficiency Anemia," Final Research Report and Egineering The Indonesian Academy of Sciences, 2010. www.km.ristek.go.id accessed on August 28, 2015.

[16] Rebelato A. P., Pacheco B. C., Prado J. P., Pallano J. A. L., "Iron Fortified biscuits: a Simple method for its Quantification bioaccessibility study and physicochemical quality," Food research International, vol/issue: 77(3), 2015

[17] National Standardization Agency, "The Quality Requirements of Biscuit," Jakarta, BSN, pp. 2-9, 2011. (SNI 73782009).

[18] Mervina, Kusharto C. M., Marliati S. A., "Formulation of biscuits with Clarias glariepinus and soy protein isolat (Glycine max) as potential Food for Nutrition Deficiency Toddler," J. Tehnol dan Industri pangan, vol/issue: 23(1), 2012 . 